\title{
Impact of Soil Albedo and Transpiration on Heavy Metals Uptake by Plant
}

\author{
Zaky, M.H. and Gehan, G. Abdel-Ghany \\ Desert research center, mataria, cairo, Egypt
}

\begin{abstract}
A field study was conducted in the summer season of 2017 in the Agricultural Experimental Station of Desert Research Center (D R C), Wadi Suder, South Sinai, to evaluate the effect of sewage sludge on soil albedo, evaporation and plant transpiration and to study the potential impact of transpiration and albedo on heavy metals mobility factors. In general, adding sewage sludge to calcareous soil increase soil organic matter and soil Whatever, transpiration correlates with plant lifetime, therefore it increased as life time increase. The accumulation of elements was generally higher in the root as compared by shoot and grains. The enrichment factor (EF) of $\mathrm{Zn}, \mathrm{Cu}$, pb and $\mathrm{Cd}$ increased by increasing sewage sludge application rates and reached to $41,62,87$ and $240 \%$ for $\mathrm{Zn}, \mathrm{Cu}, \mathrm{Pb}$ and $\mathrm{Cd}$, respectively. Concerning the effect of soil albedo which decreases as increasing soil organic matter and sorghum lifetime, the last same percents of increasing in enrichment factors (EF) ratio were achieved by decreasing soil albedo. The data of bioaccumulation factor (BF) revealed that elevated transpiration led to the increase of metal uptake and bioaccumulation factors of the studied heavy metals, the concentration ratio reached $41,46,41$ and $52 \%$ for $\mathrm{Zn}, \mathrm{Cu}, \mathrm{Pb}$ and $\mathrm{Cd}$, respectively. Meantime, $\mathrm{BF}$ ratios reached 54, 58, 59 and $53 \%$ for the previous sequence of metals. Transpiration show a non-significant relation with $\mathrm{Zn}$ transport, also the negative relation achieved for $\mathrm{Cu}$ and $\mathrm{Cd}$ while $\mathrm{Pb}$ increased by increasing transpiration. Translocation factors values of heavy metals reach $0.57,0.42,0.58$ and 0.19 for $\mathrm{Zn}, \mathrm{Cu}, \mathrm{Pb}$ and $\mathrm{Cd}$, respectively. Finally, plants with a high $\mathrm{BF}$ and low TF have the potential and ability to sequestrate most contaminants from sludge amended soil in roots consequently prevent reaching to the beneficial part of plant.
\end{abstract}

Keywords: Soil albedo, Transpiration and Enrichment, Bioaccumulation and Translocation factors.

\section{INTRODUCTION}

There are several factors which can affect the uptake mechanism of heavy metals including plant transpiration - soil albedo- plant species- properties of medium-plant roots exudates, organic acids such as citrate and oxalate, which affect the bioavailability of metals-) Seuntjens et al. (2004).

The potential impact of plant transpiration and soil albedo on some heavy metals uptake by plant was studied. With respect to transpiration, water, evaporating from plant leaves, serves as a pump to absorb nutrients and other soil substances into plant roots. This process, termed evapotranspiration, is responsible for moving contaminants into the plant shoots as well. Since contaminants are transport from roots to the shoots, which are harvested, contamination is removed while leaving the original soil undisturbed. Some plants that are used in phytoextraction strategies are termed "hyperaccumulators." There are some plants that achieve a shoot-to-root metal concentration ratio greater than one. Nonaccumulating plants typically have a shoot-to-root ratio considerably less than one. Ideally, hyperaccumulators should can grow up in toxic environments, require little maintenance and produce high biomass, although few plants perfectly fulfill these requirements Salido et al. (2003).

The effects of transpiration on Cd uptake have both been confirmed by Salt et al.,(1995)and Nanthi et al (2011), they reported that enhancement of evapotranspiration, thereby reducing the leaching of contaminants thus increase its uptake. Page et al.( 2012) reported that heavy metals are transported with the transpiration stream in the xylem from the roots to transpiring shoot parts. Also, Sharif (2001) decided that high transpiration rates produced more $\mathrm{Cd} / \mathrm{Zn}$ uptake than the low transpiration rate. Therefore, increasing $\mathrm{Cd}, \mathrm{Cu}$ and $\mathrm{Zn}$ doses had significant effect on the accumulation of these elements in the plant parts (stem, leaves and roots). The mean uptake of all three metals by sunflower plants increased as transpiration and the concentration of these metals in the soil increased. Lucia et al.2011.and SELLERS, P. J. (1985), studied the relation of canopy reflectance of transpiration on heavy metals uptake, and they found a significant relation among canopy reflectance and transpiration on the plant uptake. On the other side, heavy metals have also the inverse effect on plant transpiration. With regard to this, Nagajyoti et al.(2010), reported that anthropogenic activities may seriously influence the accessibility of heavy metals in the environment. Heavy metals may abruptly damage the vital physiological process of the cells including the gaseous exchange, $\mathrm{CO}_{2}$ fixation, respiration and nutrient absorption potential. A number of biotic as well as a biotic factors such as temperature, soil $\mathrm{pH}$, soil aeration, moisture, type of plants their size and root systems, competition between the plants and the accessibility of elements in soil highly influence metals uptake rates in plants.

In addition, Transpiration rates were reduced to $59,60,55$ and $48 \%$ of those in the control plants at 
3, 10, 20 and $30 \mu \mathrm{M} \mathrm{Cd}$, respectively. Suzana $A$. Sayed (1997).

Surface albedo is an important variable in regulating the energy balance of the earthatmosphere interface. For a given surface, surface albedo is defined as the ratio of reflected shortwave to the incoming shortwave $(0.3-3 \mathrm{~lm})$ of solar radiation. Wang et al.(2005). Soil albedo may impact on metals uptake directly or indirectly through influencing soil moisture, evaporation and soil temperature which affected directly on transpiration thereon, Metal mobility is influenced by soil properties such as albedo, organic matter and oxides as well as soil structure and profile development. Soil type, vegetation, hydrology, land use and biological activity play a key role in longterm patterns of metal mobility Kouame et al.,( 2010); Ashraf et al.,(2012).

Idso et al., (1975), reported that Surface albedo was inversely related to surface soil moisture. Particularly, surface albedo was a linear function of the soil moisture of the very thin surface layer $(<0.2$ $\mathrm{cm}$ ), an-d surface albedo corresponded slightly to the soil moisture of depths $>2 \mathrm{~cm}$. also the same results achieved by Gascoin et al.(2009); Roxy et al(.2010). The $\mathrm{Cu}^{2+}$ adsorption capacity decrease with increasing temperature so, the ability to uptake increase. Penpun Tasaso (2014). Therefore, the main objective of this study is to investigate the effect of soil albedo and transpiration on contaminants uptake by plant.

\section{MATERIAL AND METHODS}

The field experiment was carried out in summer season of 2017 in a split design in which the main plot was represented by three sewage sludge application rates, $(0,0.5$ and $1 \%$. w/w dry weight basis), with three replicates, the experimental layout was as follow: 3 rates of sludge $\times 3$ replicates $=9$ plots. Irrigation water added only at $30 \%$ depletion of available water. After soil preparation, plots were divided into lines/ plot and sown by grain sorghum (sorghum bicolor), (after seeds primed in water for about twenty four hour, at 14 pits / line at 20 th April 2018.

\section{The field Measurements:}

Soil albedo was measured monthly by using Digital Lux Meter (LX 1330B). Soil evaporation was determined according to Yan, et al. (2012). Mechanical analysis was carried out by the international pipette method of Kilmer and Alexander (1949). Soil moisture was percent determined in soil directly by using profile prop (PR2). Enrichment factor, bioaccumulation factor and translocation factor were calculated according to Singh et al. (2010). Transpiration calculated as the difference between evapotranspiration and evaporation. In which evapotranspiration equal to evaporation of the free water surface and plant transpiration Richard et al. (1990). Organic matter (O.M) was determined as well as organic carbon (O.C) according to Jackson (1973) . The electrical conductivity was measured using 4075 Conductivity TDS meter described by Jackson (1973). The $\mathrm{pH}$ values of soil solution were measured by $3010 \mathrm{pH}$ meter According to Black, et al., (1983). Total heavy metals contents in soils under study $(\mathrm{Zn}, \mathrm{Cu}$, $\mathrm{Pb}$ and $\mathrm{Cd}$ ) were measured by the Ionic Coupled Plasma, after digestion of the samples with a ternary acids mixture of $\mathrm{HNO}_{3}, \mathrm{H}_{2} \mathrm{SO}_{4}$ and $\mathrm{HClO}_{4}$ acids according to Hesse (1971). DTPA- extraction forms of available heavy metals were extracted from studied soil according to Lindsay WL and Norvell $W A$ (1978). The initial physical and chemical properties of wadi suder soil and irrigation water are shown in Table (1).

\section{RESULTS AND DISCUSSION}

\section{Albedo of studied soil:}

Calcareous soil defined by low ability to moisture and heat retention, also by raising bare soil albedo and alkalinity. Thus, affect on heavy metal solubility and uptake by plant.

Also, calcareous soil is characterized as light colored one, so increasing reflectance of solar radiation. Consequently, affecting plant transpiration therefore, organic matter and plant stages effects were studied to obvious their role in improvement reflectance state. The data in Table (2) pointed out that soil albedo decreased by increasing organic matter and plant lifetime. This increase reaches 13.4 and 5\% for organic matter and plant, respectively. While the interaction of organic matter and plant liftime resulted in decreasing of albedo to $16.8 \%$. Fig (1) illustrate the inverse relation among soil albedo, organic matter and plant lifetime and the simple correlations were $\mathrm{r}=-0.992 * * *$ and $\mathrm{r}=$ $0.975^{* * *}$ for the same last sequence. This means that organic matter plays the prime role in improving soil albedo. This is was due to changing of soil surface color and retained excessive moisture content.

\section{Transpiration:}

Transpiration is coupled to a suite of complex species dependent physical, chemical and biological processes and is strongly influenced by the natural environment in which the plants live. Evaporation from either plant tissues or bare soil surfaces requires four necessary factors: energy input, presence of liquid water, Fugacity and a transport mechanism. Nobel, 1991. In general, the present study focus on transpiration as affected by plant lifetime and soil albedo. Thus Table (2) and Fig (2) show that soil albedo has the inverse relation with transpiration where decreasing albedo by $3.68,4.24$ and $6.04 \%$ led to increasing transpiration by 300 , 318 and $324 \%$, respectively. 


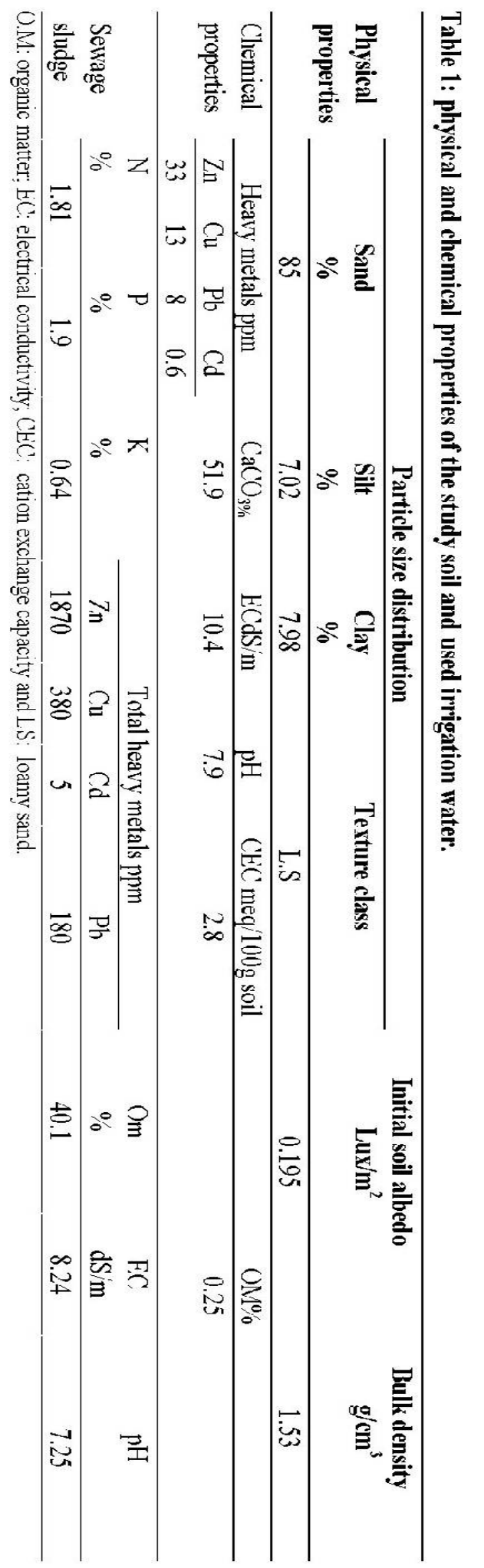


Table 2: Some soil parameters and plant transpiration.

\begin{tabular}{ccccccc}
\hline $\begin{array}{c}\text { sludge } \\
\mathbf{\%}\end{array}$ & $\begin{array}{c}\text { Plant Livetime } \\
\text { (Day) }\end{array}$ & $\begin{array}{c}\text { Moisture } \\
\mathbf{\%}\end{array}$ & $\begin{array}{c}\text { OM } \\
\mathbf{\%}\end{array}$ & $\begin{array}{c}\text { Soil albedo } \\
\mathbf{L u x} / \mathbf{m}^{\mathbf{2}}\end{array}$ & $\begin{array}{c}\text { Evaporation } \\
\mathbf{m m}\end{array}$ & $\begin{array}{c}\text { Transpiration } \\
\mathbf{m m}\end{array}$ \\
\hline \multirow{3}{*}{0} & 30 & 16.3 & 0.22 & 0.190 & 11.59 & 34.79 \\
\cline { 2 - 7 } & 100 & 17.3 & 0.22 & 0.187 & 48.65 & 162.86 \\
\hline \multirow{2}{*}{1} & 140 & 18.5 & 0.23 & 0.183 & 38.78 & 141.61 \\
\cline { 2 - 7 } & 30 & 27.3 & 0.35 & 0.182 & 9.86 & 33.01 \\
\hline \multirow{2}{*}{2} & 100 & 29.7 & 0.34 & 0.176 & 48.36 & 161.07 \\
\hline & 140 & 30.1 & 0.33 & 0.171 & 35.72 & 140.26 \\
\hline & 30 & 31.8 & 0.37 & 0.165 & 8.83 & 31.3 \\
\hline
\end{tabular}
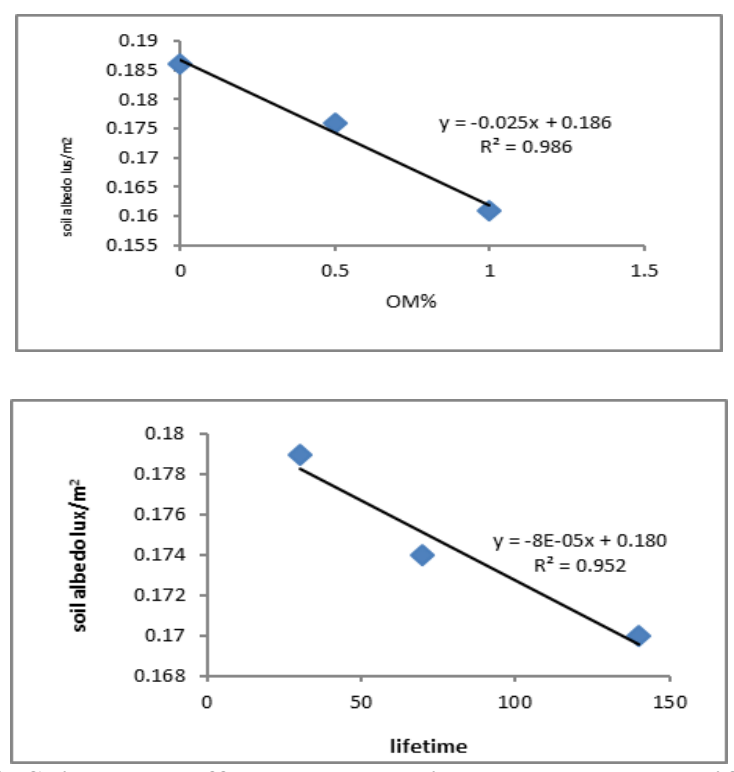

Fig. 1: Soil albedo affected by organic matter and plant lifetime
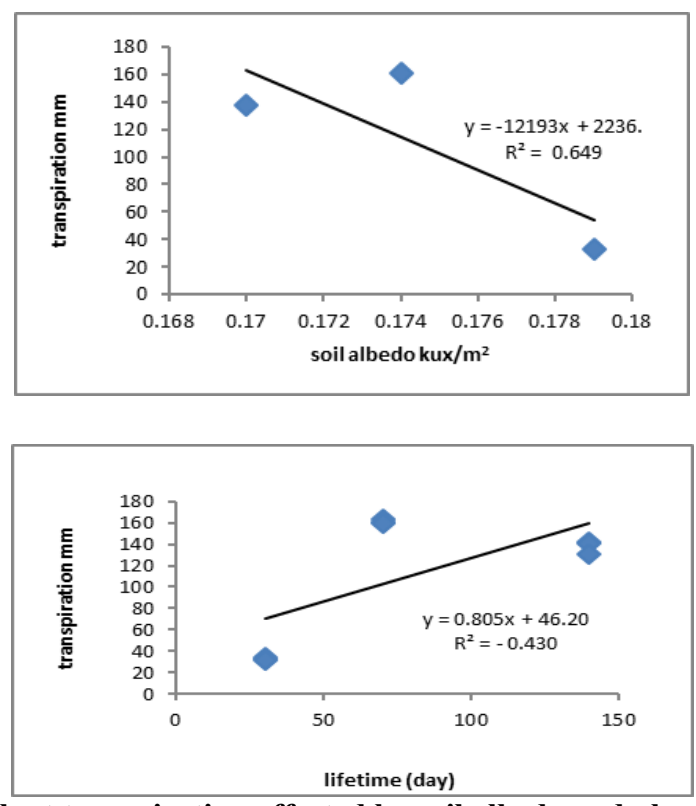

Fig. 2: plant transpiration affected by soil albedo and plant lifetime 
Whilst, plant stage shows a positive relation so, transpiration increased by $315 \%$ as a result of raising plant growing. The simple correlations were $\mathrm{r}=-0.805^{* *}$ and $\mathrm{r}=0.655^{*}$ for albedo and plant stage respectively. The previous data of transpiration pronounces that transpiration increase by decreasing soil albedo, this result assure that increasing transpiration refer to increasing plant reflectance which correlated significantly with canopy size.

Heavy metals accumulation in plant tissues:

Table (3) pointed out that all studied heavy metals increased by increasing sludge levels such increase reached to $44,120,38$ and $200 \%$ for $\mathrm{Zn}$, $\mathrm{Cu}, \mathrm{Pb}$ and $\mathrm{Cd}$, respectively. These variations attributed to variation in availability of elements in alkalinity conditions. Regarding, contaminants in plant tissues increased as sludge application increased and strongly impact the metal content of plant tissues. The accumulation of elements was generally higher in the root followed by shoot and grains. Also, the same Table revealed that plant root superiority on the other tissues which contain about $41,46,41$ and $52 \%$ for $\mathrm{Zn}, \mathrm{Cu} \mathrm{Pb}$ and $\mathrm{Cd}$, respectively. While, the little ratios were for grain as 23, 24, 23.6 and 9 for the last same order of elements. It was seemed that $\mathrm{Cd}$ content in the grain was minimized in comparison with other elements this was due to the initial amount of element in soil and sludge. The uptake and accumulation of heavy metals by plant was attributed to cultivation on sludge amended soils. Previous studies have reported the accumulation of toxic metals in different plants and tissues after their growth on sludge amended soil Heckman et al (1987) and Mazen (1995).

Enrichment factor (EF):

The enrichment factor was calculated for the studied elements. It expresses how much of heavy elements reach to the sludge mended soil and calculated as the ratio between the concentration of heavy metals in contaminated soil and uncontaminated soil. And the value greater than one indicate environmental pollution Singh et al. (2010). With respect to the (EF) of $\mathrm{Zn}, \mathrm{Cu}, \mathrm{pb}$ and $\mathrm{Cd}$ Table (4) shows that these values increased by increasing sewage sludge additives and reach 41, 62, 87 and $240 \%$ for $\mathrm{Zn}, \mathrm{u}, \mathrm{Pb}$ and $\mathrm{Cd}$ respectively. These increase maybe due to decaying of sludge and producing organic acids that consequently affected the $\mathrm{pH}$ value of calcareous soil and increase the availability of elements. In concern, the effect of soil albedo which decreases as increasing soil organic matter, the same percents of increasing in EF value were achieved by decreasing soil albedo as a result of raising soil temperature hence increase organic matter decaying and element solubility and availability to uptake by plant. Fig (3) describes the linear relation among EF, soil albedo and organic matter where, soil albedo show the inverse effect on $\mathrm{EF}$ and the simple correlation values were: $0.991 * * *,-0.999 * * *,-0.996 * * *$ and $-0.985 * * *$ for $\mathrm{Zn}, \mathrm{Cu}, \mathrm{Pb}$ and $\mathrm{Cd}$ respectively. Also organic matter show the positive relation with correlation values $0.999 * * *, 0.994 * * *, 0.980 * * *$ and $0.960 * * *$ for the previous sequent of elements.

Table 3: heavy metals accumulation in plat tissues.

\begin{tabular}{|c|c|c|c|c|c|}
\hline \multirow[t]{2}{*}{ Sludge \% } & \multirow[t]{2}{*}{ Plant tissue } & \multicolumn{4}{|c|}{ Heavy metals ppm } \\
\hline & & $\mathbf{Z n}$ & $\mathrm{Cu}$ & $\mathbf{P b}$ & $\mathbf{C d}$ \\
\hline \multirow{3}{*}{$0.0 \%$} & Root & 16.23 & 6.010 & 5.63 & 0.23 \\
\hline & Shoot & 13.60 & 5.450 & 4.62 & 0.19 \\
\hline & grain & 9.200 & 3.100 & 3.20 & 0.05 \\
\hline \multirow{3}{*}{$0.5 \%$} & Root & 19.98 & 8.530 & 6.43 & 0.50 \\
\hline & Shoot & 15.93 & 6.500 & 5.87 & 0.37 \\
\hline & grain & 11.09 & 4.450 & 4.11 & 0.10 \\
\hline \multirow{3}{*}{$1 \%$} & Root & 22.90 & 10.57 & 7.70 & 0.90 \\
\hline & Shoot & 19.30 & 8.230 & 6.49 & 0.47 \\
\hline & grain & 14.20 & 6.300 & 4.80 & 0.15 \\
\hline
\end{tabular}

Table 4: Enrichment factor (EF)

\begin{tabular}{lcccc}
\hline Sludge \% & \multicolumn{4}{c}{ Heavy metals } \\
\cline { 2 - 5 } & $\mathbf{Z n}$ & $\mathbf{C u}$ & $\mathbf{P b}$ & $\mathbf{C d}$ \\
\hline $0.0 \%$ & 0.9 & 0.85 & 0.87 & 0.83 \\
\hline $0.5 \%$ & 1.09 & 1.07 & 1.12 & 1.33 \\
\hline $1 \%$ & 1.27 & 1.38 & 1.63 & 2.83 \\
\hline
\end{tabular}



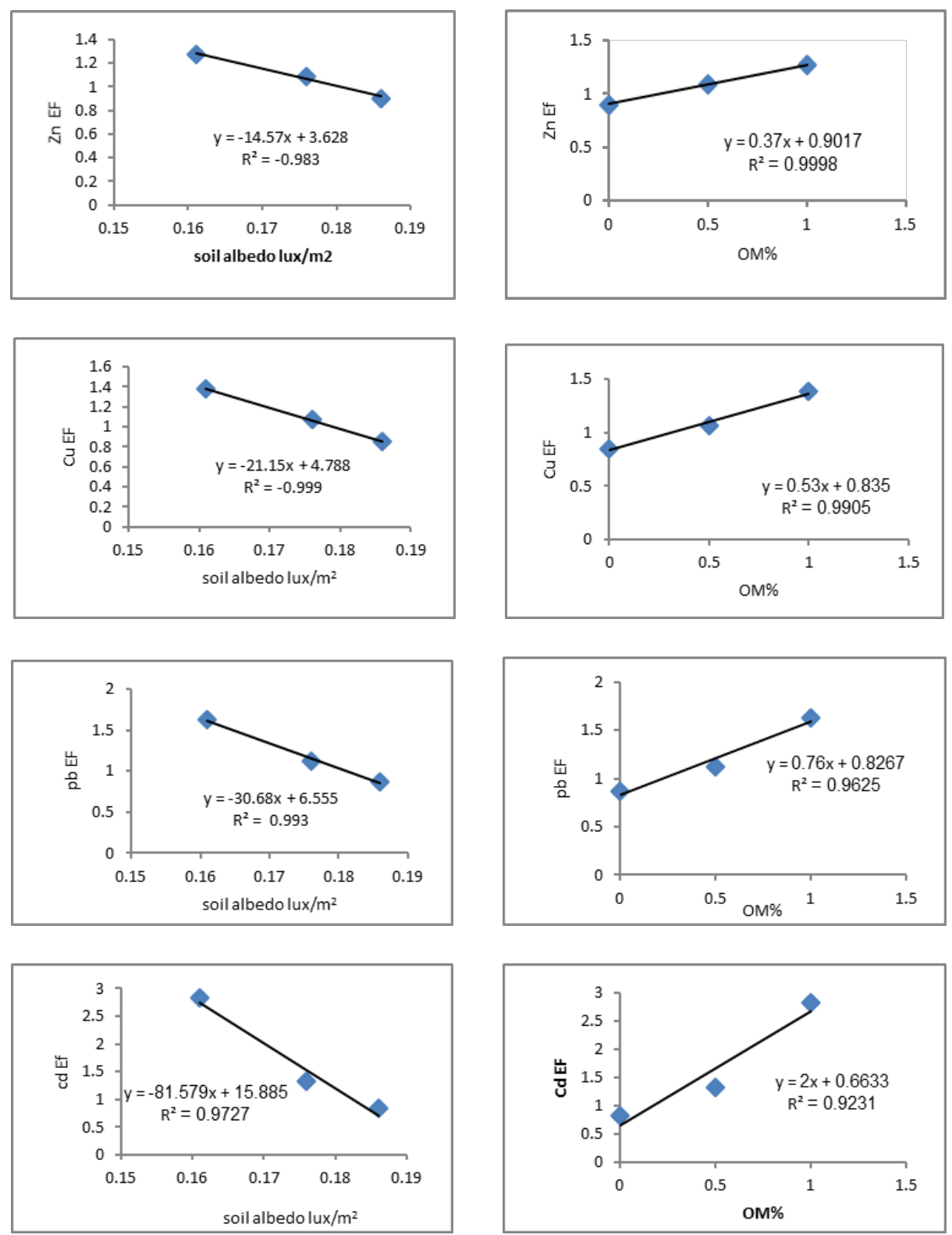

Fig. 3: Enrichment factors (TF) of $\mathrm{Zn}, \mathrm{Cu}, \mathrm{Pb}$ and $\mathrm{Cd}$ affected by soil albedo and organic matter.

\section{Bio accumulation Factor (BF)}

Bio accumulation Factor (BF), can b defined as the metal concentration ratio of plant roots to soil. Heavy metals transport to root tissue depends upon some factors i.e: concentration of heavy in soil solution, plant roots exudats, organic acids such as citrate and oxalate and the transpiration factor. Elevated level of metals in root may be attributed to the high sludge concentration of metals or the transpiration rate that consider as a pump thus it take up the soil solution within root tissue also reduce soil albedo increase soil temperature thus the availability of elements to uptake by roots. in general Tables $(3 \& 5)$ show that elevated transpiration rate increased the uptake of metals and bioaccumulation factors of them, the concentration ratio reach $41,46,41$ and $52 \%$ for $\mathrm{Zn}, \mathrm{Cu}, \mathrm{Pb}$ and $\mathrm{Cd}$, respectively. In the same time $\mathrm{BF}$ ratio reach 54 , 58,59 and $53 \%$ for the previous sequence of metals. Fig (4) demonstrated these relations that painted to the positive linear relation between transpiration and bioaccumulation factor of the studied heavy metals. The simple correlation values were: $0.999 * * *$, $0.904^{* * *}, 0.626^{*}$ and $0.912^{* * *}$ for $\mathrm{Zn}, \mathrm{Cu}, \mathrm{Pb}$ and $\mathrm{Cd}$, respectively. 
Table 5: bioaccumulation and translocation factors of heavy metals.

\begin{tabular}{lcccc}
\hline Lifetime & \multicolumn{4}{c}{ Bioaccumulation factor of heavy metals } \\
\cline { 2 - 5 } & $\mathbf{Z n}$ & $\mathbf{C u}$ & $\mathbf{P b}$ & $\mathbf{C d}$ \\
\hline 30 & 0.5 & 0.55 & 0.80 & 0.46 \\
\hline 100 & 0.55 & 0.60 & 0.71 & 0.62 \\
\hline 140 & 0.54 & 0.58 & 0.59 & 0.53 \\
\hline \multicolumn{5}{c}{ Translocation factors } \\
\hline 100 & 0.56 & 0.51 & 0.56 & 0.22 \\
\hline 140 & 0.55 & 0.52 & 0.63 & 0.2 \\
\hline
\end{tabular}
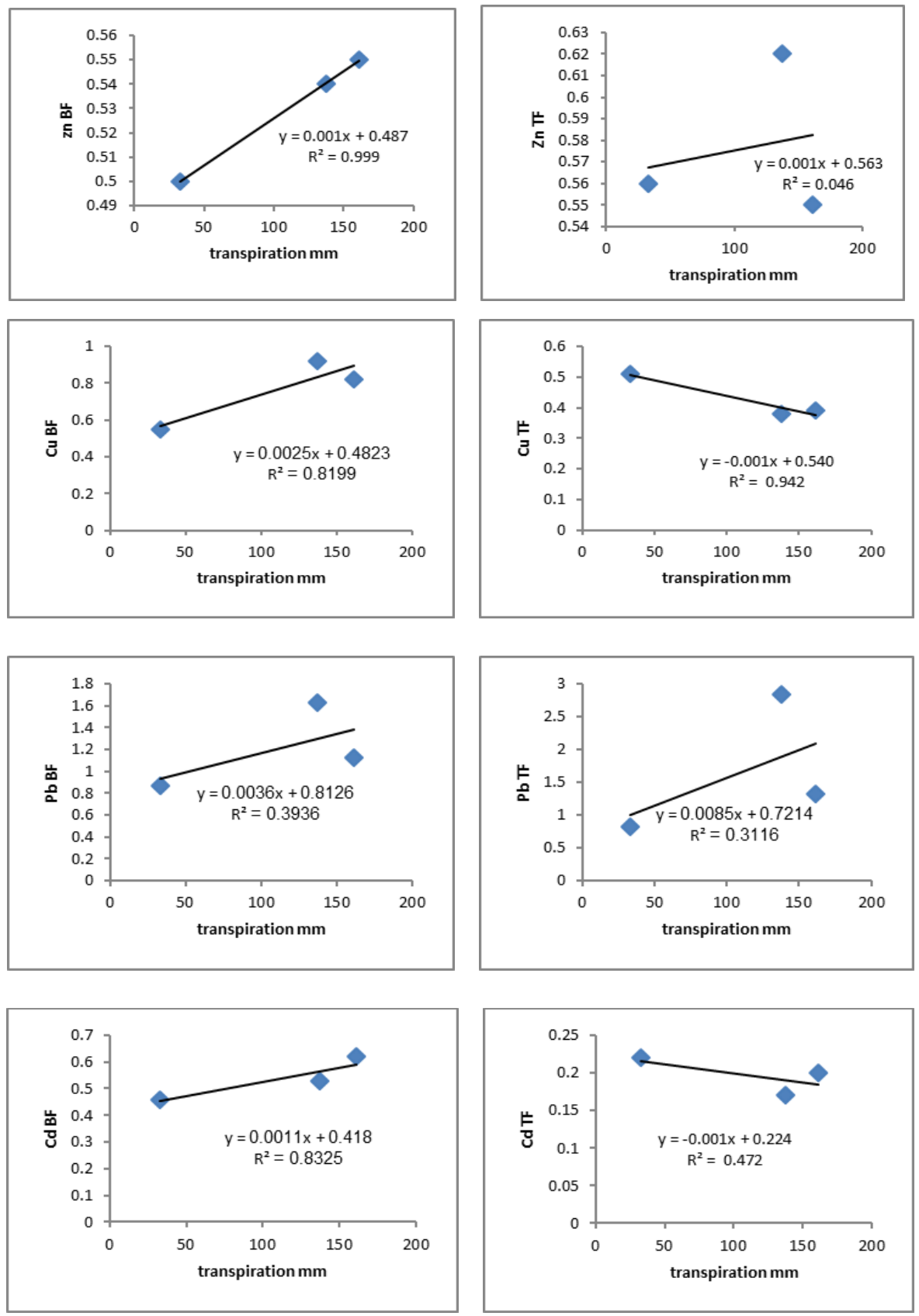

Fig. 4: heavy metals bioaccumulation and translocation factors affected by transpiration. 
According to the correlation coefficient values, it seem that the highly significant correlation was for $\mathrm{Zn}$ with transpiration and this was maybe refer to concentration of metals in sludge. Meantime, the little coefficient of $\mathrm{Pb}$ due to the high molecular weight (207.2)

\section{Translocation factor (TF):}

This parameter express the quantity of contaminants were translocated by transpiration from root to grains. It was calculated as the ratio of contaminants in grains to roots. The translocation factor does not depend on concentration of elements in soil but on some physiological process within plant majid et al. (2012).

The low amounts of metal in grain indicated that sorghum could sequestrate high level of metals in roots. The data of heavy metal accumulation shown in Tale (3) and Fig (4) declared that grain yield has the little amount of contaminants comparing to shoot and root, meanwhile the transpiration show a non-significant relation with $\mathrm{Zn}$ transport also the negative relation achieved for $\mathrm{Cu}$ and $\mathrm{Cd}$ while $\mathrm{Pb}$ increased by increasing transpiration .

Table (5) illustrates TF values of heavy metals which represent $0.57,0.42,0.58$ and 0.19 for $\mathrm{Zn}$, $\mathrm{Cu}, \mathrm{Pb}$ and $\mathrm{Cd}$, respectively. The simple correlation values were: $0.214 \mathrm{NS},-0.985^{* * *}, 0.557^{*}$ and $0.687^{*}$ for $\mathrm{Zn}, \mathrm{Cu}, \mathrm{Pb}$ and $\mathrm{Cd}$ sequently.

\section{CONCLUSION}

In summary, sewage sludge applications increased total and available metal concentrations in the soil of current study. Available heavy metals concentrations in soil solution were closely correlated to the sludge total metal concentrations. The increase in soil metal concentrations did not translate within soil profile rapidly leading to increases in metal accumulation sorghum root zone. Linear relationships were observed between concentration metals in soil and metal uptake by roots. Zinc was the metal with the greatest uptake by roots followed by $\mathrm{Cu}, \mathrm{Pb}$ and $\mathrm{Cd}$.

In general, despite the increase in root tissue concentrations of metals, plant uptake mechanisms clearly restricted metal transport to aerial parts. Moreover, transferring heavy metals into sorghum grain could be considered highly significant with transpiration and sludge applications to soil. Soil albedo correlated significantly with sewage sludge additives and plant live time in which increased sludge additives and plant lifetime decreased soil albedo consequently increased plant transpiration. Enrichment factor negative significantly increased by decreasing soil albedo meantime the positive one achieved with soil organic matter. The bioaccumulation factor correlated significantly with transpiration while translocation factor show a non significant relation for $\mathrm{Zn}$ and negative relation for
$\mathrm{Cu}$ and $\mathrm{Cd}$ meantime $\mathrm{Pb}$ increased by increased translocation factors. Generally, Plants with a high $\mathrm{BF}$ and low TF have the potential and ability to sequestrate most contaminants from sludge amended soil in roots consequently prevent reaching to the beneficial part of plant.

\section{REFERENCES}

Ashraf, M.A., M.J. Maah and I. Yusoff, 2012. Chemical speciation and potential mobility of heavy metals in the soil of former tin mining catchment. Sci. World J., 2012: 11-11. DOI: 10.1100/2012/125608.

Black, C.A. (1983). "Methods of Soil Analysis". Part 1. Agron series No. 9, Am. Soc .Agron .Mad.Wise., U.S.A.

Gascoin S, Ducharne A, Ribstein P, Perroy E, Wagnon P (2009). Sensitivity of bare soil albedo to surface soil moisture on the moraine of the Zongo glacier (Bolivia). Geophys Res Lett 36:1-5

Heckman, J. R.; Angle J. S. and Chaney, R. L. (1987), Residual effects of sewage sludge on soybean: II. Accumulation of soil and symbiotically fixed nitrogen. J. Environ. Qual., 16 (2), 118-124.

Hesse, P. R. (1971). A textbook on soil chemical analysis. William Clowe and Sons Limited, London.

Idso SB, Jackson RD, Reginato RJ, Kimball BA, Nakayama FS (1975). The dependence of bare soil albedo on soil water content. J Appl Meteorol Clim 14: 109-113

Jackson, M.L. (1973). Soil chemical analysis. Prentice -Hall, Inc England Clif, New Jersey, U.K

Kilmer, V.J. and L.T., Alexander, (1949). Methods of making mechanical analysis of soils, Soil, Sci., 68, 15

Kouame, I.K., B. Dibi, K. Koffi, I. Savane and I. Sandu, 2010. Statistical approach of assessing horizontal mobility of heavy metals in the soil of akouedo landfill nearby ebrie lagoon (abidjan-cote d'Ivoire). Int. J. Conservat. Sci., 1: $149-160$

Lindsay, W. L. and Norvell, W. A. (1978). Development of a DTPA soil test for Zink, iron, manganese and copper. Soil Sci. Soc. Amer. Proc. 42:421-428.

Lucia,H. G. C., M. A. Estrela and R. S. Souza, 2011. Effect on plant growth and heavy metal accumulation by sunflower journal of phytology, 3(12): 04-09. 
Mazen, A. M. A. (1995), assessment of heavy metal accumulation and performance of some physiological parameters in Zea mays and Vicia faba L grown on soil amended by sewage sludge resulting from sewage water treatment in the State of Qatar. Qatar Univ. Sci. J., 15(2), 353-359.

Majid, N.M., M.M. Islam, R.A. Rauf, P. Ahmadpour and A. Abdu, 2012. Assessment of heavy metal uptake and translocation in Dyera costulata for phytoremediation of cadmium contaminated soil. Acta Agric. Scand., 62: 245-250. DOI: 10.1080/09064710.2011.603740

Nagajyoti PC, Lee KD, Sreekanth TVM 2010 .Heavy metals, occurrence and toxicity for plants: A review. Environ Chem Lett 8: 199216.

Nanthi S. Bolan, Jin Hee Park, Brett Robinson, Ravi Naidu, and Keun Young Huh 2011. Phytostabilization: A Green Approach to Contaminant Containment. Advances in Agronomy, Volume 112

Nobel, P. S. 1991. Physiochemical and Environmental Plant Physiology, 635 pp., Academic, Boston, Mass

Page, V.; Blösch, R.M.; Feller, U. 2012. Regulation of shoot growth, root development and manganese allocation in wheat (Triticum aestivum) genotypes by light intensity. Plant Growth Regul, 67, 209-215, doi:10.1007/s10725-012-9679-1.

Penpun Tasaso 2014. Adsorption of Copper Using Pomelo Peel and Depectinated Pomelo Peel. Journal of Clean Energy Technologies, Vol. 2, No. 2 ,

SELLERS, P. J. 1985. Canopy reflectance, photosynthesis and transpiration INT. J. REMOTE SENSING, VOL.6, No. 8, 13351372.

Richard G.A., Luis S.P., Dirk R. and Martin S. 1990. Crop evapotranspiration, guidelines for computing crop water requirements.Irrig.\& Drain. Paper, No. 56, FAO, Rom, Italy.
Roxy MS, Sumithranand VB, Renuka G 2010. Variability of soil moisture and its relationship with surface albedo and soil thermal diffusivity at Astronomical Observatory, Thiruvananthapuram, south Kerala. J Earth Syst Sci 119: 507-517

Salido, A. L., K. L. Hasty, J. M. Lim, and D. J. Butcher 2003. "Phytoremediation of arsenic and lead in contaminated soil using Chinese Brake ferns (Pteris vittata) and Indian mustard (Brassica juncea)," International Journal of Phytoremediation, vol. 5, no. 2, pp. 89-103.

Salt DE, Prince RC, Pickering IJ \& Raskin I (1995). Mechanisms of cadmium mobility and accumulation in Indian mustard. Plant Physiology 109: 1427-1433.

Seuntjens, P., B. Nowack, and R. Schulin, 2004. "Root-zone modeling of heavy metal uptake and leaching in the presence of organic ligands," Plant and Soil, vol. 265, no. 1-2, pp. 61-73.

Sharif A. S. 2001. Heavy Metals Uptake by Wheat Under Two Transpiration Rates. M.S.C. Thesis department of agricultural and Biosystems Engineering McGiII University Macdonald Campus.

Singh, R., D.P. Singh, N. Kumar, S.K. Bhargava and S.C. Barman, 2010. Accumulation and translocation of heavy metals in soil and plants from fly ash contaminated area. J. Environ. Biol., 31: 421-430. PMID: 21186714

Suzan A. Sayed 1997. Effect of cadmium and kinetin on transpiration rate, stomatal opening and leaf relative water content in safflower plants. Journal of Islamic Academy of Sciences 10: 3, 73-80-1997.

Wang KC, Wang PC, Liu JM, Sparrow M, Haginoya S, Zhou XJ 2005. Variation of surface albedo and soil thermal parameters with soil moisture content at a semi-desert site on the western Tibetan Plateau. Bound Layer Meteorol 116: 117-129.

Yan, H., Zhang C., Oue, H. 2012. Comparison of different methods for estimating soil surface evaporation in a bare field. Meterology and Atmospheric Physics. 118, 143-149. 


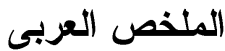

\section{تأثير البيدو التربة والنتح على امتصاص النبات للعناصر الثقيلة}

\section{مجدى حسن ذكى، جهان جمال عبد الغنى

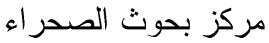

اقيمت تجربة حقلية فى صبف Y V P فى محطة بحوث رأس سدر (مركز بحوث الصحر اء) لتقييم اثر اسنخدام

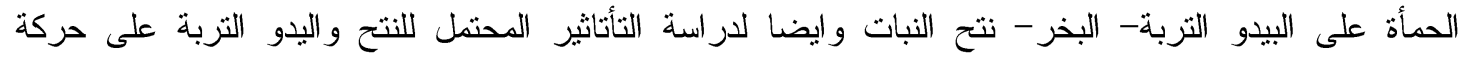
و امتصاص العناصر التقبلة. بوجه العموم فإن اضافة الحمأة للار اضى الجيرية ادى لزيادة كحتو اها من المادة العضوية ومحتو اها الرطوبى وققلل معدل البخر وقل انعكاس التربة لأشعة الثمس و ايضا نتح النبات. ارتبط معدل النتح بعر النبات معنويا حيث زاد النتح بزيادة عمر النبات. لوحظ ان تز اكم العناص كان اكثر

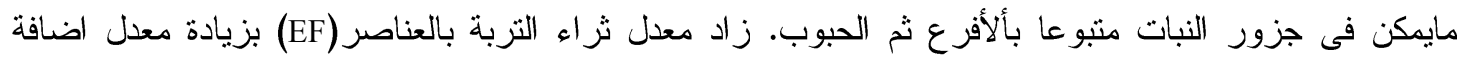

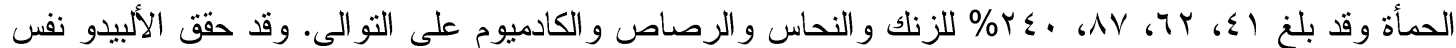

$$
\text { نسب التأثنر السابقة. }
$$

وقد اثشارت البيانات الخاصة بمعامل التراكم الحيوى (BF) الى ان امتصاص العناصر زاد بزيادة النتح. وكانت

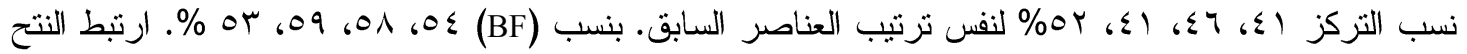

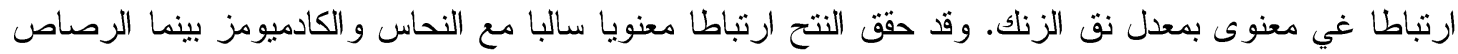

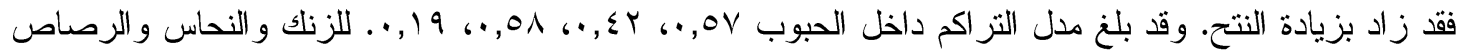

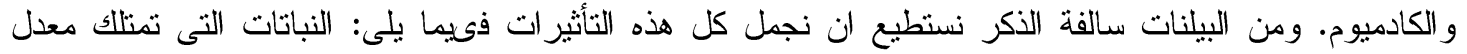
تز اكم فى الجزور(BF) اعلى من معدل النقل الى الحبوب (TF) فإنها تنتلك القدرة على تخزين الملوثات فى جزورها

$$
\text { ومنعها من الوصول للجزء النافع للغذاء الآدمى و الحيو انى. }
$$

